УДК 663.252 .61

DOI 10.30679/2219-5335-2021-2-68-215-231

ОРГАНИЧЕСКИЕ КИСЛОТЫ И КАТИОНЫ В СТРУКТУРНЫХ ЭЛЕМЕНТАХ ЯГОДЫ ВИНОГРАДА И ВИНОМАТЕРИАЛАХ

Власова Ольга Константиновна канд. техн. наук ведущий научный сотрудник лаборатории биохимии и биотехнологии e-mail: vlasov-ok43@yandex.ru

Даудова Татьяна Идрисовна ст. научный сотрудник лаборатории биохимии и биотехнологии e-mail: batuch@yandex.ru

Гасанов Расул Закирович мл. научный сотрудник лаборатории биохимии и биотехнологии e-mail: gacanov@bk.ru

Прикаспийский институт биологических ресурсов обособленное подразделение Федерального государственного Бюджетного учреждения науки Дагестанского федерального исследовательского иентра Российской академии наук, Махачкала, Россия

Шелудько Ольга Николаевна д-р техн. наук зав. научным центром «Виноделие» e-mail: scheludcko.olga@yandex.ru

Ширшова Анастасия Александровна канд. техн. наук научный сотрудник научного центра «Виноделие» e-mail: anastasiya_1987@inbox.ru

Абакумова Алла Андреевна аспирант научный сотрудник научного центра «Виноделие» e-mail: kgau.0701@mail.ru
UDC 663.252.61

DOI 10.30679/2219-5335-2021-2-68-215-231

\section{ORGANIC ACIDS AND CATIONS \\ IN STRUCTURAL ELEMENTS OF GRAPE BERRIES AND WINE MATERIALS}

\author{
Vlasova Olga Konstantinovna \\ Cand. Techn. Sci. \\ leading Research Associate \\ of Biochemistry \\ and Biotechnology Laboratory \\ e-mail: vlasov-ok43@yandex.ru \\ Daudova Tatyana Idrisovna \\ Senior Research Associate \\ of Biochemistry \\ and Biotechnology Laboratory \\ e-mail: batuch@yandex.ru
}

Gasanov Rasul Zakirovich

Junior Research Associate

of Biochemistry

and Biotechnology Laboratory

e-mail: gacanov@bk.ru

Caspian Institute

of Biological Resources -

a Separate Division

of the Federal State

Budget Institution of Science

of the Daghestan Federal

Research Center

of the Russian Academy of Sciences,

Makhachkala, Russia

Sheludko Olga Nikolaevna

Doct. Techn. Sci.

Head of «Wine-making» Scientific Center

e-mail: scheludcko.olga@yandex.ru

Shirshova Anastasiya Aleksandrovna

Cand. Techn. Sci.

Research Associate

of «Wine-making» Scientific Center

e-mail: anastasiya_1987@inbox.ru
Abakumova Alla Andreevna
Post Graduate student
Research Associate
of «Wine-making» Scientific Center
e-mail: kgau.0701@mail.ru 
Федеральное государственное бюджетное научное учреждение «Северо-Кавказский федеральный научный иентр садоводства, виноградарства, виноделия», Краснодар, Россия

Наличие органических кислот и катионов в винограде и продуктах его переработки влияет на их вкус и питательные свойства. Исследованы пулы этих веществ в кожице и семенах ягоды винограда сортов Гимра новая, Каберне Совиньон, Мускат белый, Первенец Магарача и в сухих виноматериалах из сортов Гимра новая, Фиолетта и Первенец Магарача. Для определения состава и содержания органических кислот (М-04-47-2007) и катионов (М-01-32-2008), использовали систему капиллярного электрофореза «Капель-104Т», ООО НПФ «ЛЮМЭКС». В элементах структуры ягоды идентифицированы винная, уксусная и яблочная кислоты. Наибольшее их содержание $\left(0,24\right.$ г/дм $\left.{ }^{3}\right)$ выявлено в сорте винограда Мускат белый. В каждом из виноматериалов обнаружены винная, лимонная, молочная, уксусная, яблочная и янтарная кислоты. Самые значительные количества, соответственно, яблочной, янтарной и уксусной кислот - 2,39; 1,72 и 0,85 г/дм ${ }^{3}$ определены в виноматериале из сорта винограда Гимра новая, молочной кислоты - 0,27 г/дм ${ }^{3}$ из сорта Фиолетта, винной и лимонной $-6,20$ и 0,69 г/дм ${ }^{3}$ в виноматериале из сортов Гимра новая и Первенец Магарача, у которого и суммарная концентрацией кислот 10,03 г/дм ${ }^{3}$ была наиболее высокой. В кожице ягоды, семенах и виноматериалах идентифицированы катионы аммоний, калий, кальций, магний и натрий. По общему их количеству лидировали сорт Мускат белый - 174,07 мг/дм ${ }^{3}$ и виноматериал из винограда Гимра новая - 1933,57 г/дм³ ${ }^{3}$ Терруар равнины юга Дагестанского Прикаспия благоприятствует формированию пулов органических кислот и катионов в винограде, что способствует получению

\author{
Federal State \\ Budget Scientific Institution \\ "North Caucasus Federal \\ Scientific Center of Horticulture, \\ Viticulture, Wine-making», \\ Krasnodar, Russia
}

The presence of organic acids and cations in the grapes and its processing products affects their taste and nutritional properties. Pools of these substances in the berry skin and seeds of the grape varieties of Gimra Novaya, Kaberne Sovin'on, Muskat Bely, Pervenets Magaracha and in the dry wine materials from the Gimra Novaya, Fioletta and Pervenets Magaracha varieties were studied. To determine the composition and content of organic acids (M-04-47-2007) and cations (M-01-32-2008), a capillary electrophoresis system was used - "Kapel-104T",

LLC NPF "LUMEX”. Tartaric, acetic and malic acids are identified in the elements of the berry structure. Their largest content $\left(0.24 \mathrm{~g} / \mathrm{dm}^{3}\right)$ is revealed in the Muskat Bely grapes. In each of the wine materials the tartaric, citric, lactic, acetic, malic and succinic acids are found. The most significant amounts, respectively, of malic, succinic and acetic acids - 2.39; 1.72 and $0.85 \mathrm{~g} / \mathrm{dm}^{3}$ were determined in the wine material from the Gimra Novaya grape variety, and the lactic acid $-0.27 \mathrm{~g} / \mathrm{dm}^{3}$

from the Fioletta variety, wine and citric acids -6.20 and $0.69 \mathrm{~g} / \mathrm{dm}^{3}$ were determined in the wine material from the Gimra Novaya variety and Pervenets Magaracha, in which the total concentration of acids $-10.03 \mathrm{~g} / \mathrm{dm}^{3}$ was the highest. In the skin of the berry, seeds and wine materials the cations of ammonium, potassium, calcium, magnesium and sodium are identified. In terms of their total number, the Muscat white variety $-174.07 \mathrm{mg} / \mathrm{dm}^{3}$ and wine material from Gimra Novaya grape $-1933.57 \mathrm{mg} / \mathrm{dm}^{3}$ were the leaders.

The terroir of the South of the Daghestan Caspian Sea plain is favorable for the formation of pools of organic acids and cations in the grapes, which contributes 
Плодоводство и виноградарство Юга России № 68(2), 2021 г.

из него виноматериалов с высоким энологическим потенциалом.

Ключевые слова: ВИНОГРАД, ОРГАНИЧЕСКИЕ КИСЛОТЫ, КАТИОНЫ, СТРУКТУРНЫЕ ЭЛЕМЕНТЫ ЯГОДЫ ВИНОГРАДА, ВИНОМАТЕРИАЛЫ, ТЕРРУАР to the production of wine materials with high enological potential.

Key words: GRAPES, ORGANIC ACIDS, CATIONS, STRUCTURAL ELEMENTS OF GRAPE BERRIES, WINE MATERIAL, TERROIR

Введение. Большое значение для характеристики полезных свойств вин имеют находящиеся в кожице ягоды и семенах винограда, а также в виноматериалах органические кислоты, которые могут присутствовать в них, находясь как в свободном, так и в связанном состоянии - в составе солей и эфиров. Формирование органических кислот происходит вследствие окислительной диссоциации сахаров и неполного окисления аминокислот, при этом особую роль играют энзиматические преобразования в цикле Кребса. Синтезу органических кислот в листьях растений способствует слабое освещение, а в корнях - поглощенная углекислота.

Интенсивность транспорта органических кислот из корней и листьев в грозди зависит от того, насколько здоров куст и в каких экологических условиях он выращивается. Превращению углеводов в органические кислоты в корнях благоприятствуют присутствие соединений фосфора и находящиеся в почве микроорганизмы. Важность органических кислот заключается в том, что они являются исходным продуктом для биосинтеза углеводов, аминокислот и белков, активно участвуют в образовании свойств вин высокого качества - обусловливают ощущение свежести во вкусе и являются косвенными участниками процесса составления их изысканного букета $[4,5]$.

Известно, что накопление органических кислот в плодах растений, в том числе и ягодах винограда, связано с сортовой специфичностью, общим физиологическим состоянием растений, возрастом, стадией развития, условиями их питания и влагообеспечения [6-10]. Состав и концентрация представителей пула органических кислот виноградного сырья при производстве виноматериалов в результате физико-химических превращений, 
а также в связи с жизнедеятельностью различных микроорганизмов, изменяются. Дрожжи и бактерии при сбраживании сусла потребляют органические кислоты. Например, дрожжами усваиваются лимонная, яблочная, винная и янтарная кислоты $[4,5]$.

Тема изучения химического состава элементов структуры ягоды винограда остается актуальной на протяжении ряда лет как у нас в стране $[11,12]$, так и за рубежом [13-19]. Из кожицы и семян виноградных ягод можно получать пищевые добавки, увеличивающие не только потребление клетчатки, фенольных соединений, но полезных для здоровья органических кислот и неорганических катионов.

Целью работы являлось исследование состава пулов органических кислот и катионов в кожице ягод и семенах винограда, культивируемого на территории Дагестана, а также в виноматериалах, изготовленных из автохтонных сортов винограда Гимра новая, Фиолетта и интродуцированного сорта Первенец Магарача. На наш взгляд, такая постановка вопроса важна для характеристики влияния природных факторов терруара на качество и функциональность винограда, выращиваемого в определенных экологических условиях, и продуктов его переработки. Изучение состава и определение массовых концентраций органических кислот и катионов в структурных элементах ягоды винограда и в виноматериалах, изготовленных с использованием автохтонных сортов, способствует получению информации, объясняющей оригинальность сенсорных, иммунологических и профилактических свойств этих натуральных продуктов.

Объекты и методы исследований. Изучали состав и содержание органических кислот (винной, яблочной, янтарной, лимонной, уксусной, молочной ) и катионов(аммония, калия, кальция, магния, натрия) в кожице и семенах ягод винограда сортов Гимра новая, Каберне Совиньон, Мускат белый, Первенец Магарача) и в опытных образцах красных и розовых су- 
хих виноматериалов, изготовленных в лабораторных условиях (классическая технология, сырье - виноград сортов Гимра новая, Фиолетта и Первенец Магарача). Для успешного сбраживания сусла использовали чистую культуру дрожжей, выделенную сотрудниками нашей лаборатории из местной микробиоты, обитающей в экологических условиях терруара виноградные плантации Дагестанской селекционной опытной станции виноградарства и овощеводства (г. Дербент, Республика Дагестан).

Известно, что метеорологические условия - тепло, освещенность и влажность имеют большое значение для получения качественного урожая винограда, и их совокупное влияние в течение года всегда доминирует над крю, то есть комплексом почвенно-климатических условий определенного участка виноградников. Два климатических года и два года урожая никогда не могут быть одинаковыми. По определению французских виноделов, для производства вина высокого качества их сырьём должен служить виноград, выращиваемый в условиях местности, где сумма активных температур (CAT) превышает $3100{ }^{\circ} \mathrm{C}$; число дней в году с максимальной $\mathrm{T}^{\mathrm{o}}$ выше $30{ }^{\circ} \mathrm{C}$ - больше 15; годовых осадков - 250-385 мм; инсоляция - примерно 1300 ч. Принято считать, что метеорологические условия июня (период цветения) определяют количество урожая винограда, а погода в августе обеспечивает его качество [1].

Природные условия южной равнинной зоны Дагестана (особенно приморской, где расположены опытные участки под посадками изучаемых сортов винограда) соответствуют этим требованиям. Они характеризуются значительными среднегодовыми температурами; средними температурами самого теплого месяца. САТ здесь $3700-3800{ }^{\circ} \mathrm{C}$, условный баланс влаги 0,54, среднегодовое количество осадков, выпадение которых увеличивается в июле, сентябре и октябре - 355 мм. Почва светло-каштановая, суглинистая содержит в среднем 2,5-3,5 \% гумуса, до 8-10 \% карбонатов, 1,5-2 \% калия, 0,1-0,2 \% фосфора и 0,12-0,31\% азота [2, 3]. 
Определение состава и количества органических кислот и катионов в опытных образцах винограда и виноматериалов осуществляли, применяя систему капиллярного электрофореза «Капель - 104Т», ООО НПФ «ЛЮМЭКС». Пользовались методами измерения массовой концентрации органических кислот (М-04-47-2007) и катионов (М-01-32-2008), которые основаны на разделении в кварцевом капилляре исследуемых соединений, идентификации и количественном определении анализируемых компонентов химического состава изучаемых объектов, с косвенным детектированием при длине волны 254 нм. На приборе регистрировали по две электрофореграммы каждой аликвотной порции пробы опытного образца. За результат принимали среднее арифметическое значение показаний двух параллельных определений. Для получения качественных и количественных характеристик изучаемых веществ пользовались ПО «Мультихром для Windows».

Обсужнение результатов. В кожице и семенах опытных образцов винограда красных технических сортов Гимра новая, Каберне Совиньон и белых - Первенец Магарача и Мускат белый идентифицированы три органические кислоты: винная, уксусная и яблочная. Изучаемые элементы структуры ягод этих сортов различались как по составу, так и по величинам массовых концентраций, содержащихся в них кислот (табл. 1.).

В кожице ягод сорта винограда Гимра новая обнаружена лишь яблочная кислота, у сортов Каберне Совиньон, Мускат белый и Первенец Магарача - винная и яблочная. В семенах сорта Гимра новая, как и в кожице ягод этого сорта, содержалась только яблочная кислота, у сортов Каберне Совиньон и Мускат белый - уксусная, а у Первенца Магарача яблочная и уксусная. Всего в элементах структуры ягод сортов Каберне Совиньон, Мускат белый и Первенец Магарача содержалось по три вышеуказанных представителя органических кислот, а в сорте Гимра новая только одна. 
Плодоводство и виноградарство Юга России № 68(2), 2021 г.

Таблица 1 - Органические кислоты в элементах структуры ягод винограда, выращиваемого в Дагестане

\begin{tabular}{|c|c|c|c|c|}
\hline \multirow{2}{*}{$\begin{array}{c}\text { Сорт } \\
\text { винограда }\end{array}$} & \multirow{2}{*}{$\begin{array}{c}\text { Структурный } \\
\text { элемент ягоды }\end{array}$} & \multicolumn{3}{|c|}{ Концентрация кислот, г/дм ${ }^{3}$} \\
\hline & & винная & уксусная & яблочная \\
\hline \multirow{2}{*}{ Гимра новая } & Кожица & не обнаружено & не обнаружено & 0,03 \\
\hline & Семена & не обнаружено & не обнаружено & 0,01 \\
\hline \multirow{2}{*}{$\begin{array}{c}\text { Каберне } \\
\text { Совиньон }\end{array}$} & Кожица & 0,06 & не обнаружено & 0,1 \\
\hline & Семена & не обнаружено & 0,05 & не обнаружено \\
\hline \multirow{2}{*}{$\begin{array}{l}\text { Первенец } \\
\text { Магарача }\end{array}$} & Кожица & 0,05 & не обнаружено & 0,03 \\
\hline & Семена & не обнаружено & 0,06 & 0,02 \\
\hline \multirow{2}{*}{$\begin{array}{c}\text { Мускат } \\
\text { белый }\end{array}$} & Кожица & 0,07 & не обнаружено & 0,13 \\
\hline & Семена & не обнаружено & 0,04 & не обнаружено \\
\hline
\end{tabular}

Суммарные величины массовой концентрации органических кислот, имевшихся в кожице и семенах ягод каждого из исследованных сортов винограда, иллюстрирует рисунок 1. Наибольшее общее их количество определено в сорте Мускат белый - 0,24, а самое незначительное -0.04 г/дм³ в сорте Гимра новая.

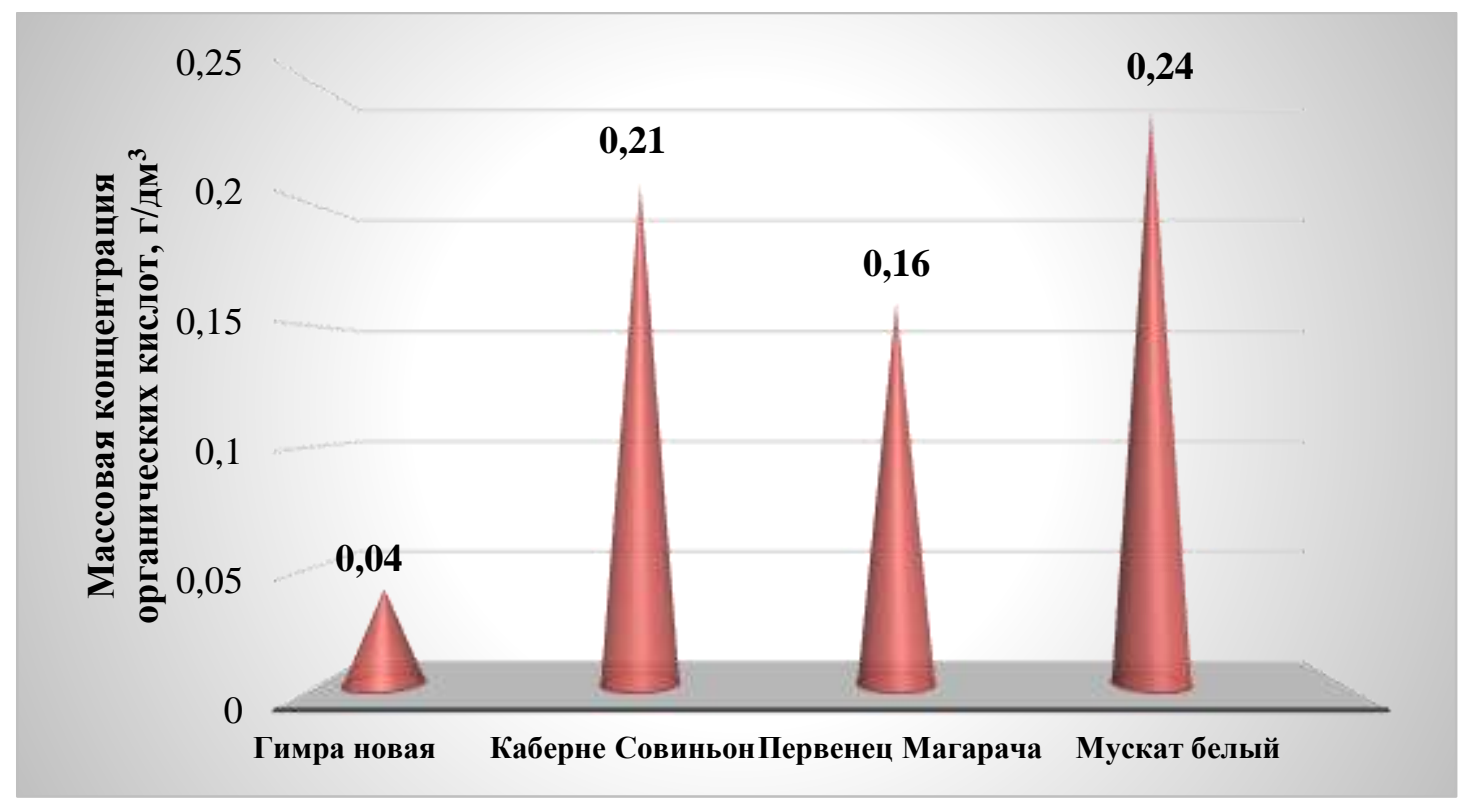

Рис. 1. Суммарная массовая концентрация органических кислот в элементах структуры ягод винограда, выращиваемого в Дагестане 
Плодоводство и виноградарство Юга России № 68(2), 2021 г.

Как было сказано выше, кроме определения содержания органических кислот в элементах структуры ягоды винограда изучался и состав пулов этих веществ в сухих красных виноматериалах, приготовленных из сортов Гимра новая и Фиолетта, а также в сухих розовых из сортов Гимра новая, Фиолетта и белого сорта Первенец Магарача. В каждом из опытных образцов идентифицировано шесть органических кислот: винная, лимонная, молочная, уксусная, яблочная и янтарная. Их количества различались в зависимости от сортов, служивших сырьем для получения виноматериалов.

Так, наибольшие массовые концентрации, соответственно, яблочной, янтарной и уксусной кислот - 2,39; 1,72 и 0,85 г/дм³ выявлены в красном виноматериале из винограда Гимра новая; винной и лимонной - 6,20 и 0,69 г/дм ${ }^{3}$ в розовом из сортов Гимра новая и Первенец Магарача; молочной кислоты - 0,27 г/дм³ в красном из сорта Фиолетта (табл. 2). Однако качество пищевого продукта определяется не только суммарным количеством находящихся в нем питательных компонентов, но и природой каждого из них, а также характером их превращений.

Таблица 2 - Органические кислоты в виноматериалах, изготовленных из винограда, выращиваемого в Дагестане

\begin{tabular}{|l|c|c|c|c|c|c|}
\hline \multirow{2}{*}{$\begin{array}{l}\text { Виноматериал } \\
\text { из сортов }\end{array}$} & \multicolumn{6}{|c|}{ Массовая концентрация кислот $\pm \delta \%$, г/дм ${ }^{3}$} \\
\cline { 2 - 7 } & винная & лимонная & молочная & уксусная & яблочная & янтарная \\
\hline Фиолетта & $2,90 \pm 0,58$ & $0,54 \pm 0,11$ & $0,27 \pm 0,05$ & $0,69 \pm 0,14$ & $1,78 \pm 0,35$ & $1,42 \pm 0,28$ \\
\hline Гимра новая & $1,94 \pm 0,39$ & $1,04 \pm 0,21$ & $0,14 \pm 0,03$ & $0,85 \pm 0,17$ & $2,39 \pm 0,47$ & $1,72 \pm 0,34$ \\
\hline $\begin{array}{l}\text { Первенец } \\
\text { Магарача } \\
\text { и Фиолетта }\end{array}$ & $5,46 \pm 1,09$ & $0,55 \pm 0,11$ & $0,14 \pm 0,03$ & $0,29 \pm 0,06$ & $1,04 \pm 0,21$ & $0,95 \pm 0,19$ \\
\hline $\begin{array}{l}\text { Первенец } \\
\begin{array}{l}\text { Магарача } \\
\text { и Гимра новая }\end{array}\end{array}$ & $6,20 \pm 1,24$ & $0,69 \pm 0,14$ & $0,20 \pm 0,04$ & $0,53 \pm 0,11$ & $1,25 \pm 0,25$ & $1,16 \pm 0,23$ \\
\hline
\end{tabular}

В трех образцах виноматериалов количество винной кислоты превалировало над содержанием других кислот, и лишь в красном виноматериале Гимра новая доминировала яблочная. Винная кислота и её калийная 
Плодоводство и виноградарство Юга России № 68(2), 2021 г.

соль в совокупности с неорганическими кислотами, как известно, определяют кислотность вина и препятствуют развитию повреждающих его микроорганизмов. Растворимость солей винной кислоты в вине ниже, чем в водно-спиртовых растворах, что объясняется, в частности, стабилизирующим действием обычно находящихся в нем аминокислот - аспартата, глицина, лейцина и фенилаланина $[4,5]$.

Следующее положение после винной кислоты по величине концентрации в виноматериалах занимала яблочная кислота - очень лабильное органическое соединение, служащее промежуточным продуктом при синтезе многих веществ, в том числе и углеводов. Между синтезами винной и яблочной кислоты нет связи. Способность винограда накапливать большие количества яблочной кислоты является особенностью сорта. Для получения гармоничных вин с хорошо выраженным сортовым ароматом применяют виноград богатый яблочной кислотой.

Яблочная кислота имеет приятный вкус, но очень большое её количество в виноградном сусле и вине вызывает резкое вкусовое ощущение, что негативно отражается на дегустационной характеристике конечного продукта $[4,5,6]$. В виноматериале из винограда Гимра новая содержание яблочной кислоты оказалось самым высоким - 2,39 г/дм³.

Концентрация янтарной кислоты в изучаемых виноматериалах была менее значительной, по сравнению с количеством винной и яблочной. В виноматериалах и винах она, в основном, образуется в результате дегидрирования и конденсации уксусной кислоты, а также при синтезе, производимом дрожжами во время спиртового брожения. Многоэтапные биохимические реакции с участием СоА способны янтарную кислоту преобразовывать в молочную $[4,5]$. Но основное количество молочной кислоты формируется путем восстановления пировиноградной кислоты, которая занимает главное положение в обмене углеводов и одно из важнейших мест в метаболизме виноградного растения. 
Образование молочной кислоты идет с участием энзима лактатдегидрогеназы, активной группой которой является НАД [6]. В исследованных виноматериалах молочной кислоты оказалось меньше других кислот (см. табл. 2.). Молочная и янтарная кислоты играют важную роль в синтетических реакциях и поддержании взаимосвязи многих процессов метаболизма. Они, в совокупности с другими важными веществами химического состава, определяют в винограде, виноматериалах и винах полезные для здоровья свойства.

Постоянным компонентом вин является уксусная кислота. В опытных образцах её количество находилось в пределах от 0,29 (розовый виноматериал из сортов Фиолетта и Первенец Магарача) до 0,85 г/дм³ (виноматериал из красного сорта Гимра новая). Уксусная кислота - это вторичный продукт спиртового брожения, который частично может формироваться за счет окисления этилового спирта. На уровень ее содержания в виноматериалах влияют расы дрожжей, вызывающие брожение, так как они могут быть ацетогенными и янтарногенными. Направление биохимических реакций в сторону образования уксусной кислоты, кроме того, зависит от температуры, концентрации сахаров в виноградном сусле $[4,5]$.

Биосинтез лимонной кислоты, содержание которой в опытных образцах виноматериалов составляло 0,54 (виноматериал из красного сорта Фиолетта) - 0,69 г/дм³ (розовый виноматериал из сортов Гимра новая и Первенец Магарача), осуществляется с участием фермента цитратсинтазы, ацетил-СоА, щавелевоуксусной кислоты и процесса конденсации. Известно, что лимонная кислота создает специфические нюансы вкуса различных типов вин $[4,5]$. Общее количество органических кислот в розовом виноматериале, приготовленном из сортов Гимра новая и Первенец Магарача, было самым большим - 10,03 г/дм³. Пул органических кислот виноматериала из красного сорта Фиолетта оказался бедным - 7,62г/дм³ (рис. 2.). 




Рис. 2. Суммарное количество органических кислот в виноматериалах из сортов винограда, выращиваемого в Дагестане

Помимо органических кислот в элементах структуры ягоды и виноматериалах были определены состав и количество катионов. Во всех опытных образцах идентифицировано по пять катионов: аммоний, калий, кальций, магний и натрий.

В кожице винограда исследованных сортов содержание аммония составляло 2,15 (Каберне Совиньон) - 11,6 мг/дм³ (Первенец Магарача); калия 49,5 (Гимра новая) - 76,9 (Мускат белый); кальция 0,88 (Каберне Совиньон) - 19,59 (Мускат белый); магния 1,43 (Каберне Совиньон) - 12 (Мускат белый); натрия 1,64 (Каберне Совиньон) - 5,79 мг/дм³ (Гимра новая).

В семенах массовая концентрация аммония колебалась в пределах 6.87 (Мускат белый) - 17,2 мг/дм³ (Гимра новая); калия 11,4 (Первенец Магарача) - 28,4 (Мускат белый); кальция 1,53 (Каберне Совиньон) - 10,6 (Первенец Магарача); магния 2,06 (Первенец Магарача) - 4,8 (Мускат белый); натрия 1,08 (Гимра новая) - 2,04 мг/дм³ (Мускат белый).

По общему содержанию в кожице и семенах аммония, магния и кальция первенство принадлежит сорту Гимра новая, натрия - сорту Пер- 
венец Магарача, калия - сорту Каберне Совиньон. Самое большое суммарное количество катионов в кожице и семенах определено у сорта Мускат белый - 174,07 мг/дм³ , а в винограде Каберне Совиньон наименьшее $-115,9$ мг/дм ${ }^{3}$ (рис. 3.).

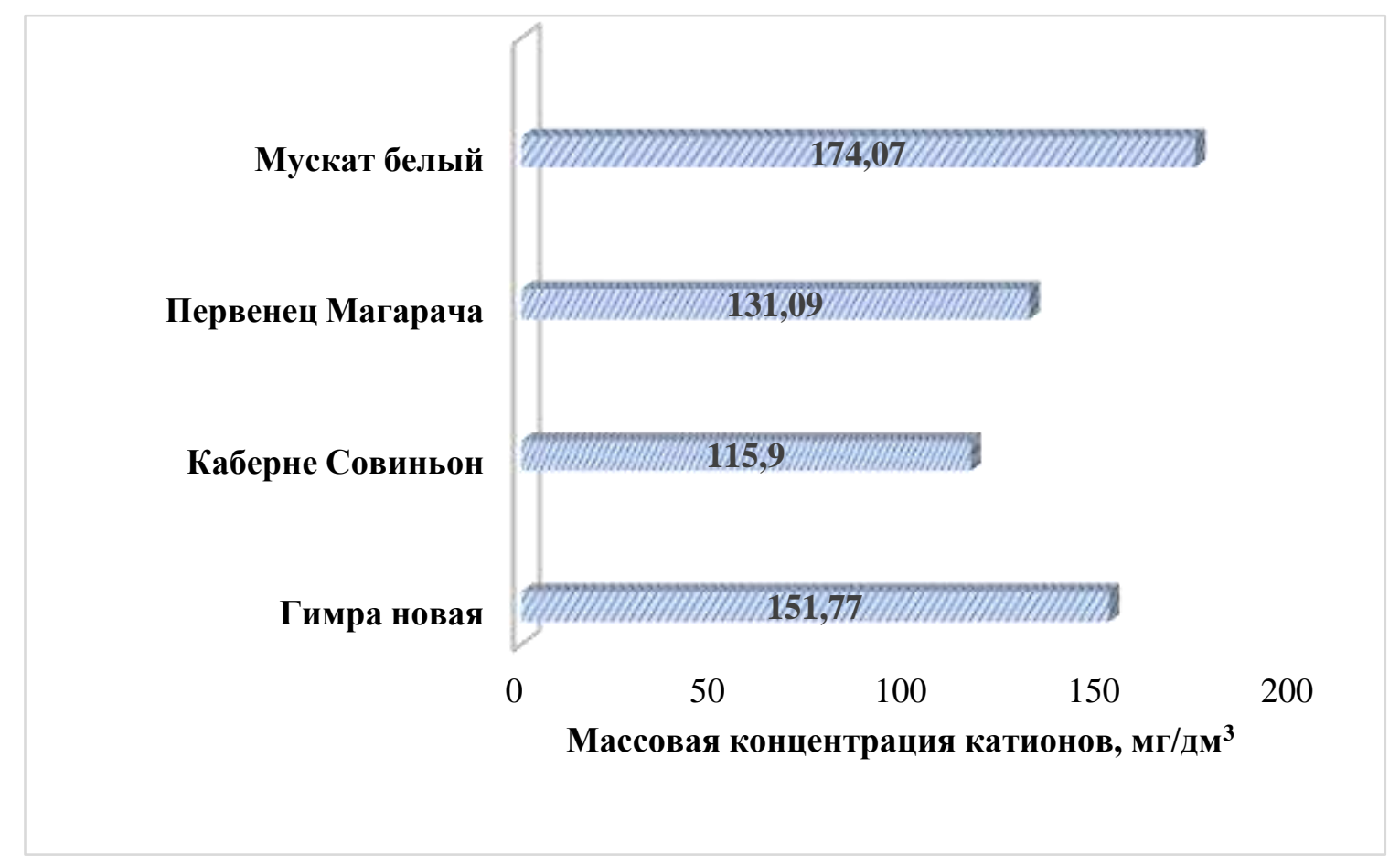

Рис. 3. Суммарная концентрация катионов в элементах структуры ягод сортов винограда, выращиваемого в Дагестане

При анализе данных, полученных при определении количества катионов в виноматериалах, выяснилось, что аммония больше всего было в розовом виноматериале из сортов Первенец Магарача и Фиолетта, а калия, кальция, магния и натрия - в красном виноматериале из автохтонного красного сорта Гимра новая (табл. 3.). Как показано на рисунке 4, по величине общей массовой концентрации обнаруженных катионов также лидировал виноматериал из сорта Гимра новая.

Идентифицированные в кожице ягоды и семенах винограда, а также в виноматериалах катионы важны для правильного течения различных процессов метаболизма. Азот аммония необходим для формирования ами- 
Плодоводство и виноградарство Юга России № 68(2), 2021 г.

нокислот и белков, калий участвует в образовании буферных систем, предотвращающих сдвиги реакций среды и обеспечивающих её постоянство. Ионы калия участвуют в проведении нервного возбуждения к мышцам, а соединения калия влияют на коллоидное состояние тканей в организме человека. Калий и натрий - антогонисты.

Таблица 3 - Содержание катионов в виноматериалах, изготовленных из винограда, выращиваемого в Дагестане

\begin{tabular}{|l|c|c|c|c|c|}
\hline \multirow{2}{*}{$\begin{array}{l}\text { Виноматериал } \\
\text { из сортов: }\end{array}$} & \multicolumn{5}{|c|}{ Массовая концентрация катионов $\pm \%$, мг/дм ${ }^{3}$} \\
\cline { 2 - 6 } & аммоний & калий & кальций & магний & натрий \\
\hline Фиолетта & $3,32 \pm 0,56$ & $973 \pm 97,3$ & $135 \pm 13,5$ & $225 \pm 24,7$ & $36,1 \pm 4,0$ \\
\hline Гимра новая & $4,27 \pm 0,73$ & $1360 \pm 136$ & $234 \pm 23,4$ & $271 \pm 29,8$ & $64,3 \pm 7,0$ \\
\hline $\begin{array}{l}\text { Первенец } \\
\text { Магарача } \\
\text { и Фиолетта }\end{array}$ & $5,93 \pm 1,01$ & $575 \pm 57,5$ & $113 \pm 11,3$ & $111 \pm 12,2$ & $15,2 \pm 1,67$ \\
\hline $\begin{array}{l}\text { Первенец } \\
\text { Магарача } \\
\text { и Гимра новая }\end{array}$ & менее 1,0 & $584 \pm 58,4$ & $172 \pm 17,2$ & $202 \pm 22,2$ & $21,4 \pm 2,35$ \\
\hline
\end{tabular}
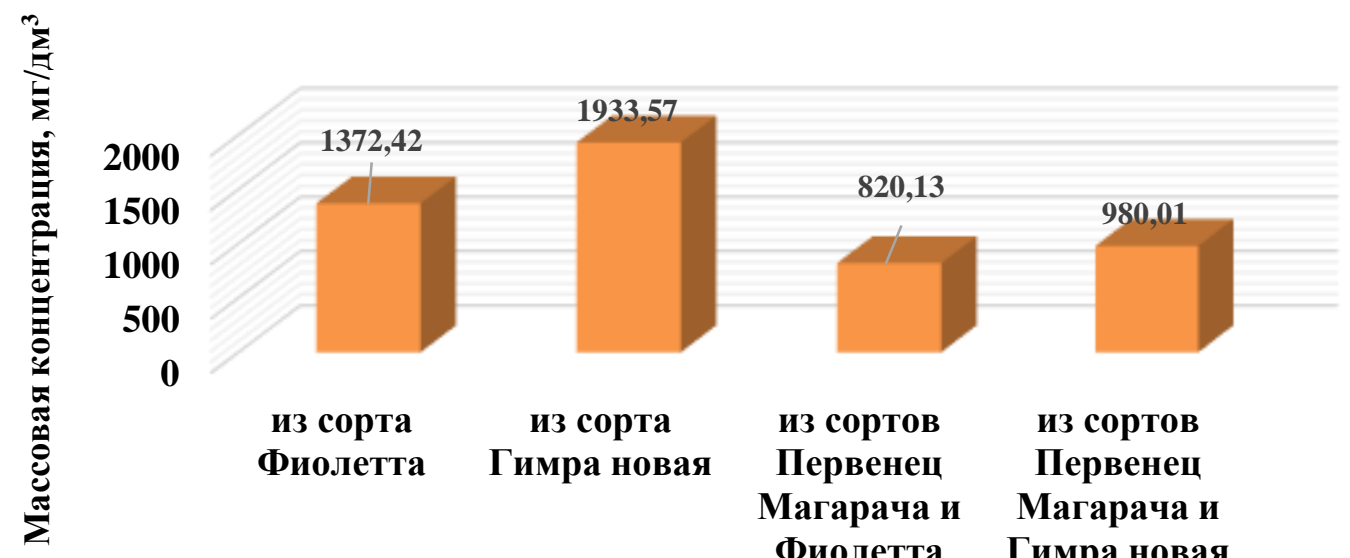
из copta
из сорта
из сортов
из сортов
Фиолетта
Гимра новая
Первенец
Первенец
Магарача и
Магарача и
Фиолетта
Гимра новая

Рис. 4. Суммарное количество катионов в виноматериалах из сортов винограда, выращиваемого в Дагестане 
Потребление большого количества натрия приводит к потере калия. Их обмен определяет соотношение внутри- и внеклеточной воды. Натрий способствует усваиванию неорганических соединений селена элемента, необходимого для укрепления иммунитета. Магний является активатором и кофактором более 300 важнейших ферментативных реакций углеводно-фосфатного и энергетического обмена, а также других процессов. Кальций - один из важных представителей группы пластических веществ различных костных структур и важнейший компонент системы свертывания крови $[4,5,20]$.

Присутствие катионов в элементах структуры ягод опытных образцов винограда и в виноматериалах характеризует их пищевые достоинства, фармакологические свойства и функциональность. Органолептическая характеристика опытных образцов виноматериалов свидетельствует о том, что они прозрачны, интенсивно окрашены, имеют своеобразный сортовой аромат и приятный вкус.

Bbыводы. Природные условия терруара южной прикаспийской равнинной зоны виноградарства в Дагестане, в частности крю виноградников Дагестанской селекционной опытной станции виноградарства и овощеводства (ФГБНУ ДСОСВиО, г. Дербент), способствуют выращиванию автохтонных красных сортов винограда Гимра новая и Фиолетта, а также интродуцированного белого сорта Первенец Магарача. Из сусел этих сортов можно производить виноматериалы с достаточным количеством органических кислот и катионов, дающим возможность высоко оценить вкус и пищевые свойства продукта.

Опытные образцы виноматериалов, изготовленные по классической технологии производства сухих вин из сортов винограда Гимра новая, Фиолетта и Первенец Магарача, выращиваемых в Дагестане, обладают высо- 
Плодоводство и виноградарство Юга России № 68(2), 2021 г.

ким энологическим потенциалом. Из них могут сформироваться вина с хорошей кислотностью и структурой, имеющие достаточно сложный цветочно-фруктовый ароматический профиль.

Сорта винограда дагестанской селекции Гимра новая и Фиолетта, наряду с такими автохтонными сортами, как Красностоп золотовский (сорт с берегов Дона), Саперави, Ркацители (южнокавказские сорта) и др., способствуют образованию в произведенных из них виноматериалах оригинального химического состава, в том числе и пулов органических кислот и катионов. Поэтому дагестанские вина из автохтонов, имеющие необычные, ценные вкусо-ароматические свойства, не характерные для вин, изготовленных из традиционных европейских сортов винограда за рубежом, особенно в странах Азии, могут восприниматься как эксклюзивный российский продукт.

\section{Литература}

1. Риберо-Гайон Ж., Пейно Э., Риберо-Гайон П., Сюдро П. Теория и практика виноделия. Т. 2. М.: Пищевая промышленность, 1979. 352 с.

2. Аджиев А.М. Виноградарство Дагестана. Махачкала: ГУ «Дагестанское книжное издательство», 2009. 287 с.

3. Баламирзоев М.А., Мирзоев Э. М-Р., Аджиев А.М., Муфараджев К.Г. Почвы Дагестана. Экологические аспекты их рационального использования. Махачкала: Дагестанское книжное издательство, 2008. 336 с. $373 \mathrm{c}$.

4. Родопуло А.К. Биохимия виноделия. М.: Пищевая промышленность, 1971.

5. Кишковский 3. Н., Скурихин И. М. Химия Вина. М.: Агропромиздат, 1988. $250 \mathrm{c}$.

6. Абрамов Ш. А., Даудова Т. И. Органические кислоты и неорганические катионы в абрикосах, выращиваемых в горных условиях Дагестана // Хранение и переработка сельхозсырья. 2009. №11. С. 11-13.

7. Абрамов Ш. А., Даудова Т. И. Виноматериалы из Ркацители предгорного Дагестана для высококачественных шампанских вин // Виноделие и виноградарство. 2010. № 5. С. 23-25.

8. Абрамов Ш. А., Даудова Т. И. Особенности накопления нутриентов в абрикоcax, произрастающих на различных высотах над уровнем моря // Почвы и растительный мир горных территорий: сборник трудов конференции «Горные экосистемы и их компоненты», Нальчик, 24-29 августа 2009 г. М.: Товарищество научных изданий КМК, 2009. С. 93-98.

9. Гусейнова Б.М., Даудова Т.И. Биохимический состав плодов абрикоса и персика, выращиваемых в различных зонах плодоводства Дагестана // Садоводство и виноградарство. 2010. № 2. С. 34-36. 
10. Гусейнова Б.М., Даудова Т.И. Содержание пектиновых веществ и витаминов в плодах дикорастущих растений Дагестана в зависимости от почвенно-климатических условий // Известия вузов. Пищевая технология. 2013. № 1(331). С. 14-16.

11. Даудова Т.И., Гусейнова Б.М. Химический состав сорта Молдова в зависимости от экологических условий места выращивания // Виноделие и виноградарство. 2010. № 6. С. 36-38.

12. Качественный и количественный состав фенольных веществ в ягодах винограда при различных условиях его выращивания / М.В. Мелконян [и др.] // Виноград и вино России. 2000. № 2. С. 12-14.

13. Casas L., Mantell C., Rodríguez M., Martínez de la Ossa E.J., Blandino A. Extraction of resveratrol from the pomace of Palomino fino grapes by supercritical carbon dioxide //Journal of Food Engineering, January. 2010. vol. 96. I. 2. pp. 304-308.

14. De Torres M.C., Schumacher R., Alañón M.E., Pérez-Coello M.S., Díaz-Maroto M.C. Freeze-dried grape skins by-products to enhance the quality of white wines from neutral grape varieties //Food Res. Int. 2015. vol. 69. pp. 97-105.

15. Teixeira A., Baenas N., Domínguez-Perles R., Barros A., Rosa E., Moreno D.A., García-Viguera C. Natural bioactive compounds from winery by products as health promoters: a review //Int. J. Mol. Sci. 2014. no.15. pp. 15638-15678.

16. Ferrari V., Taffarel S.R., Espinosa -Fuentes E., Oliveira M.L.S., Saikia B.K., Oliveira L.F.S. Chemical evaluation of by-products of the grape industry as potential agricultural fertilizers // J. Clean. Prod. 2019. vol. 208. pp. 297-306.

17. Muhlack R.A., Potumarthi R., Jeffery D.W. Sustainable wineries through waste valorisation: a review of grape marc utilisation for value-added products // Waste Manag. 2018. vol. 72. pp. 99-118

18. Rondeau P., Gambier F., Jolibert F., Brosse N. Compositions and chemical variability of grape pomaces from French vineyard //Industrial Crops and Products. 2013.vol. 43. pp. 251-254.

19. Russo D., Valentao P., Andrade P.B., Fernandez E.C., Milel1a L. Evaluation of antioxidant, antidiabetic and anticholinesterase activities of Smallanthus sonchifolius landraces and correlation with their phytochemical profiles. Int. J. Mol. Sci., 2015, No.16, pp.17696-17718.

20. Тутельян В. А., Спиричев В. К., Суханов Б. П. Кудашева В. А. Микронутриенты в питании здорового и больного человека. М.: Колос, 2002. 424 с.

\section{References}

1. Ribero-Gajon Zh., Pejno E., Ribero-Gajon P., Syudro P. Teoriya i praktika vinodeliya. T. 2. M.: Pishchevaya promyshlennost', 1979. $352 \mathrm{s.}$

2. Adzhiev A.M. Vinogradarstvo Dagestana. Mahachkala: GU «Dagestanskoe knizhnoe izdatel'stvo», 2009. $287 \mathrm{~s}$.

3. Balamirzoev M.A., Mirzoev E. M-R., Adzhiev A.M., Mufaradzhev K.G. Pochvy Dagestana. Ekologicheskie aspekty ih racional'nogo ispol'zovaniya. Mahachkala: Dagestanskoe knizhnoe izdatel'stvo, 2008. $336 \mathrm{~s}$.

4. Rodopulo A.K. Biohimiya vinodeliya. M.: Pishchevaya promyshlennost', 1971. $373 \mathrm{~s}$.

5. Kishkovskij Z. N., Skurihin I. M. Himiya Vina. M.: Agropromizdat, 1988. 250 s.

6. Abramov Sh. A., Daudova T. I. Organicheskie kisloty i neorganicheskie kationy v abrikosah, vyrashchivaemyh $\mathrm{v}$ gornyh usloviyah Dagestana // Hranenie i pererabotka sel'hozsyr'ya. 2009. №11. S. 11-13. 
7. Abramov Sh. A., Daudova T. I. Vinomaterialy iz Rkaciteli predgornogo Dagestana dlya vysokokachestvennyh shampanskih vin // Vinodelie i vinogradarstvo. 2010. № 5. S. 23-25.

8. Abramov Sh. A., Daudova T. I. Osobennosti nakopleniya nutrientov v abrikosah, proizrastayushchih na razlichnyh vysotah nad urovnem morya // Pochvy i rastitel'nyj mir gornyh territorij: sbornik trudov konferencii «Gornye ekosistemy i ih komponenty», Nal'chik, 24-29 avgusta 2009 g. M.: Tovarishchestvo nauchnyh izdanij KMK, 2009. S. 93-98.

9. Gusejnova B.M., Daudova T.I. Biohimicheskij sostav plodov abrikosa i persika, vyrashchivaemyh v razlichnyh zonah plodovodstva Dagestana // Sadovodstvo i vinogradarstvo. 2010. № 2. S. 34-36.

10. Gusejnova B.M., Daudova T.I. Soderzhanie pektinovyh veshchestv i vitaminov v plodah dikorastushchih rastenij Dagestana v zavisimosti ot pochvenno-klimaticheskih uslovij // Izvestiya vuzov. Pishchevaya tekhnologiya. 2013. № 1(331). C. 14-16.

11. Kachestvennyj i kolichestvennyj sostav fenol'nyh veshchestv v yagodah vinograda pri razlichnyh usloviyah ego vyrashchivaniya / M.V. Melkonyan [i dr.] // Vinograd i vino Rossii. 2000. № 2. S.12-14.

12. Daudova T.I., Gusejnova B.M. Himicheskij sostav sorta Moldova v zavisimosti ot ekologicheskih uslovij mesta vyrashchivaniya // Vinodelie i vinogradarstvo. 2010. № 6. S. 36-38.

13. Casas L., Mantell C., Rodríguez M., Martínez de la Ossa E.J., Blandino A. Extraction of resveratrol from the pomace of Palomino fino grapes by supercritical carbon dioxide //Journal of Food Engineering, Janu-ary. 2010. vol. 96. I. 2. pp. 304-308.

14. De Torres M.C., Schumacher R., Alañón M.E., Pérez-Coello M.S., Díaz-Maroto M.C. Freeze-dried grape skins by-products to enhance the quality of white wines from neutral grape varieties //Food Res. Int. 2015. vol. 69. pp. 97-105.

15. Teixeira A., Baenas N., Domínguez-Perles R., Barros A., Rosa E., Moreno D.A., García-Viguera C. Natural bioactive compounds from winery by products as health promoters: a review //Int. J. Mol. Sci. 2014. no.15. pp. 15638-15678.

16. Ferrari V., Taffarel S.R., Espinosa -Fuentes E., Oliveira M.L.S., Saikia B.K., Oliveira L.F.S. Chemical evaluation of by-products of the grape industry as potential agricultural fertilizers // J. Clean. Prod. 2019. vol. 208. pp. 297-306.

17. Muhlack R.A., Potumarthi R., Jeffery D.W. Sustainable wineries through waste valorisation: a review of grape marc utilisation for value-added products // Waste Manag. 2018. vol. 72. pp. 99-118

18. Rondeau P., Gambier F., Jolibert F., Brosse N. Compositions and chemical variability of grape pomaces from French vineyard // Industrial Crops and Products. 2013.vol. 43. pp. 251-254.

19. Russo D., Valentao P., Andrade P.B., Fernandez E.C., Milel1a L. Evaluation of antioxidant, antidiabetic and anticholinesterase activities of Smallanthus sonchifolius landraces and correlation with their phytochemical profiles. Int. J. Mol. Sci., 2015, No.16, pp.17696-17718.

20. Tutel'yan V. A., Spirichev V. K., Suhanov B. P. Kudasheva V. A. Mikronutrienty v pitanii zdorovogo i bol'nogo cheloveka. M.: Kolos, 2002. 424 s. 